\title{
DINAMIKA PEMIKIRAN HUKUM ISLAM DI INDONESIA
}

\author{
Zakirah Zakirah \\ Institut Agama Islam Negeri (IAIN) Sultan Amai Gorontalo, \\ Email: zakirahira17@gmail.com
}

Muhammad Arsyam

Sekolah Tinggi Agama Islam (STAI) Darul Dakwah Wal-Irsyad (DDI) Kota Makassar

Email: arsyam0505@gmail.com

Andi Andi

Sekolah Tinggi Agama Islam (STAI) Darul Dakwah Wal-Irsyad (DDI) Kota Makassar

Email: andiherlina551@gmail.com

Juhadir Juhadir

Sekolah Tinggi Agama Islam (STAI) Darul Dakwah Wal-Irsyad (DDI) Kota Makassar

Email: juhadir95mks@gmail.com

\begin{abstract}
Abstrak
Dalam perspektif ini, fikih sebetulnya tidak hanya sekedar ilmu tentang hukum-hukum syar'iyyah yang diperoleh lewat proses istidlâl, tetapi hukum-hukum itu sendiri seringkali disebut fikih. Dewasa ini, terminologi fikih tidak lagi dimaksudkan sebagai seperangkat ilmu tentang hukum, melainkan hukum-hukum fiqhiyyah itu sendiri disebut fikih. Dengan ungkapan lain, fikih adalah produk hukum yang dihasilkan ulama berdasarkan pemahaman mereka terhadap suatu nash.
\end{abstract}

\section{Kata Kunci : Dinamika, Pemikiran, Hukum Islam.}

\section{A. Latar Belakang}

Terma hukum Islam merupakan istilah khas Indonesia, karena istilah ini tidak ditemukan dalam khazanah Islam (al-turâts al-islâmî), kecuali istilah al-syarî'ah alislâmiyah (syariat Islam) dan al-fiqh al-islâmî (fikih Islam). Syariat adalah ketentuan Allah yang disyariatkan kepada hamba-hamba-Nya. ${ }^{1}$ Ketentuan itu meliputi akidah, ibadah, akhlak dan mu'amalah, ${ }^{2}$ yang tertuang dalam al-Quran dan hadis Nabi saw. Sedangkan fikih, dalam terminologi ushûliyyûn (pakar ushul fikih) didefinisikan sebagai "Ilmu tentang hukum-hukum syara' yang bersifat praktis yang digali dari dalil-dalil yang terperinci."3 Atau dalam terminologi Mannâ' al-Qaththân, fikih adalah "kompilasi hukum syara' yang bersifat praktis yang diambil dari dalil yang terperinci”. ${ }^{4}$ Dengan

${ }^{1}$ Fârûq Nabhân, al-Madkhal li al-Tasyrî‘ al-Islâmî (Beirût: Dâr al-Shadr, t. th.), h. 13. 14.

${ }^{2}$ Mannâ‘ al-Qaththân, Al-Tasyrî‘ wa al-Fiqh fî al-Islâmî (Riyâdh: Muassasah al-Risâlah, t. th.), h.

${ }^{3}$ Muhammad Abû Zahrah, Ushûl al-Fiqh, (Mesir: Dâr al-Fikr al-'Arabî, t. th.), h. 56; Saifuddîn al'Âmidî, Al-I $\underline{h} k \hat{a ̂ m}$ fî̀ Ushûl al-A $\underline{k} k \hat{a} m$, Jil. I (Kairo: Muassasah al-Halabî, 1967), h. 8.

${ }^{4}$ Mannâ' al-Qaththân, Târikh al-Tasyrî‘ al-Islâmî: Al-Tasyri ‘ wa al-Fiqh, (Riyâdh: Maktabah alMa'ârif, 1422 H), h. 183. 
demikian, terminologi syariat tidak sama dengan fikih. Syariat lebih bersifat umum, sedangkan fikih bersifat khusus; berkenaan dengan aspek hukum. Dalam al-Quran syariat identik dengan agama. Sedangkan fikih merupakan pemahaman mendalam tentang agama. ${ }^{5}$ Karena itu, syariat sifatnya ilâhiyât, permanen, sakral, dan tingkat kebenarannya pasti (qath iyyât). Sedangkan fikih sifatnya insâniyât, berubah, profan, dan tingkat kebenarannya relatif, debatable. ${ }^{6}$

Dalam khazanah hukum di Indonesia, istilah hukum Islam adalah terjemahan dari Islamic Law. Joseph Schacht mendefinisikan Islamic Law sebagai keseluruhan khitab Allah yang mengatur kehidupan setiap individu muslim dalam segala aspek kehidupannya. ${ }^{7}$ Sementara menurut Muhammad Muslihuddin hukum Islam adalah sistem hukum produk Tuhan, kehendak Allah yang ditegakkan di atas bumi. hukum Islam itu disebut syariat, atau jalan yang benar. Al-Quran dan hadis merupakan dua sumber utama dan asli bagi hukum Islam tersebut. ${ }^{8}$ Sedangkan Hasbi ash-Shiddieqy mendefinisikan hukum Islam sebagai koleksi daya upaya para ahli hukum untuk menerapkan syariat atas kebutuhan masyarakat. ${ }^{9}$ Dua pengertian hukum Islam pertama lebih dekat kepada pengertian syariat Islam atau hukum syara'. Sementara difinisi terakhir lebih dekat kepada pengertian fikih.

\section{B. Produk Pemikiran Hukum Islam}

Dalam sejarah perkembangan pemikiran hukum Islam, ada empat produk hukum Islam. Pertama, fikih, yaitu opini ulama hukum yang tertuang dalam kitab-kitab fikih. Kitab fikih yang dimaksud adalah karya-karya ulama yang disusun dan dikodifikasi sejak

${ }^{5}$ Q.S. al-Mâidah/5: 48, Q.S. al-Syûrâ/42:13, dan Q.S. al-Jâsyiah/45: 18.

${ }^{6} J u h a y a$ S. Praja, "Dinamika Hukum Islam,"dalam Jaih Mubarak, Sejarah dan Perkembangan Hukum Islam (Bandung: Rosda Karya, 2000), h. vii.

${ }^{7}$ Joseph Schacht, An Intoduction to Islamic Law (Oxford: Clarendon Press, 1993), h. 1.

${ }^{8}$ Muhammad Muslihuddin, Philosofhy of Islamic Law and Orientalist: A Comparative Study of Islamic Legal System,(Lahore, Pakistan: Islamic Publication, t.th.), h. xii.

${ }^{9}$ Hasbi ash-Shiddieqy, Filsafat Hukum Islam (Semarang: Pustaka Rizki Putra, 2001), h. 91. 
abad ke II Hijriyah. Keseluruhan opini hukum yang tertuang dalam kitab-kitab fikih ini dikategorikan sebagai fikih klasik.

Kedua, fatâwâ (fatwa-fatwa ulama). Secara etimologis, fatwa berarti, petuah, nasehat dan jawaban atas pertanyaan yang berkaitan dengan hukum. ${ }^{10}$ Secara terminologi, fatwa dimaknai sebagai pendapat yang dikemukakan seorang mujtahid atau fakih sebagai jawaban yang diajukan oleh peminta fatwa dalam suatu kasus yang sifatnya tidak mengikat. ${ }^{11}$ Dengan kata lain, fatwa adalah pendapat hukum yang tidak mengikat yang dikeluarkan untuk menanggapi persoalan hukum. ${ }^{12}$

Makna defenitif ini menunjukkan bahwa pertama, fatwa adalah sebuah opini hukum yang dikeluarkan oleh seorang mufti. Proses pembentukan opini hukum tersebut menggunakan metode ijtihad tertentu. Kedua, fatwa bersifat dinamis. Fatwa lahir untuk menanggapi persoalan hukum. Tanggapan hukum tersebut bukan muncul secara tiba-tiba dan atau atas kemauan mufti, melainkan atas permintaan atau pertanyaan yang diajukan. Karena itu, ketika Majelis Ulama Indonesia (MUI) mengeluarkan fatwa: "Haram Golput", lalu sebagaian orang ada yang menyatakan bahwa perkara Golput adalah wilayah politik dan bukan wilayah agama, sehingga MUI tidak perlu mengeluarkan fatwa. Tentu peryataan ini adalah keliru, fatwa MUI tersebut dipahami berasal dan muncul dengan sendirinya dari MUI sendiri. Sementara fatwa tersebut lahir atas pertanyaan atau sebagai tanggapan atas persoalan hukum. Tegasnya, fatwa MUI tidak keluar dengan sendirinya, melainkan 3 ıum karena adanya pertanyaan yang diajukan kepada MUI. Berdasarkan pertanyaan itu, MUI -melalui Komisi Fatwa-nya memberikan

${ }^{10}$ Sofyan A. P. Kau, Metode Penelitian Hukum Islam (Gorontalo: Sultan Amai Press, 2009), h. 18.

${ }^{11}$ Abdul Aziz Dahlan, et al., Ensiklopedi Hukum Islam (Jakarta: Ichtiar Baru Van Hoeve, 1996), Vol. 2, h. 326.

${ }^{12}$ Khaled M. Abou El Fadl, Speaking in God's Name: Islamic Law, Authority, and Women, terj. R. Cecep Lukman Yasin, Atas Nama Tuhan Dari Fikih Otoriter ke Fikih Otoritatif (Cet. I; Jakarta: Serambi Ilmu Semesta, 2004 ), h. 542. 
jawaban. Jadi, jawaban yang berupa opini hukum itu (fatwa) dikeluarkan MUI bukan atas dasar keinginan semata, melainkan atas dasar permintaan dan pertanyaan. Pertanyaan dan atau permintaan bisa bersifat perseorangan dan kolektif, dan bisa juga datang dari lembaga pemerintah.

Betapa pun "keras" dan "radikal" sebuah fatwa, namun tidak mengikat bagi setiap orang dan tidak memiliki konsekuensi serta akibat hukum yang ketat. Dengan ungkapan lain, jika fatwa itu diabaikan oleh seorang peminta fatwa, maka negara tidak dapat memaksanya untuk melakukan dan atau meninggalkannya. Meskipun fatwa tidak memiliki konsekuensi legal bagi kaum muslim, namun dapat berdampak sosial dan politik. Sebab, fatwa bukanlah pernyataan awam, tapi pernyataan sebuah otoritas agama. ${ }^{13}$

Majelis Ulama Indosesia (MUI) adalah salah satu lembaga fatwa yang didirikan tahun 1975. Selain MUI, lembaga fatwa lainnya adalah Bahtsul Masail. Bahtsul Masail adalah lembaga fatwa yang ada di Nahdhatul Ulama (NU). Di Muhammadiyah, dinamakan Majelis Tarjih. Sementara di Persis disebut Dewan Hisbah. Fatwa yang dikeluarkan oleh keempat lembaga fatwa sebagai opini hukum adalah hasil kerja intelektual maksimal secara kolektif (ijtihâd jamâ' î). Sebaliknya, fatwa yang diberikan oleh seorang mufti sebagai respon reaktif dan proaktif atas persoalan umat dikategorikan sebagai ijtihâdfardî (usaha sungguh-sungguh pengerahan daya intelektual seorang muftî). Karena itu, fatwa bukanlah keputusan hukum yang dibuat dengan gampang dan seenak perut orang, yang disebut membuat-buat hukum tanpa dasar (al-tahakkum). Fatwa senantiasa terkait dengan siapa yang berwewenang memberi fatwa (ijâzah al-iftâ'), kode

\footnotetext{
${ }^{13}$ Luthfi Assyaukanie, Islam Benar Versus Islam Salah (Jakarta: Kata Kita, 2007), h. 164.
} 
etik fatwa (adâb al-iftâ') dan metode pembuatan fatwa (istinbâth). ${ }^{14}$ Tegasnya, seorang muftî adalah seorang yang memiliki otoritas dalam bidang hukum Islam.

Ketiga, qadhâ, yaitu keputusan-keputusan pengadilan agama.

Keempat, qânun. Yaitu peraturan perundang-undangan yang ada di negeri-negeri Islam. Peraturan hukum yang diundangkan tersebut berorientasi kepada kepentingan dan kemaslahatan warga negara setempat. Karena itu, setiap aturan hukum dalam negeri muslim tidak selalu sama. Tegasnya, setiap negeri Islam memiliki peraturan perundangan tersendiri. Misalnya dalam persoalan poligami. Menurut Undang-Undang Perkawinan No. 1 Tahun 1974 dan Kompilasi Hukum Islam (KHI) poligami dibolehkan dengan sejumlah syarat. Sementara di Turki, seseorang yang akan melakukan pernikahan harus terlebih dahulu memberi keterangan kepada pengadilan bahwa ia sedang tidak berada dalam suatu ikatan perkawinan. Bila ia lakukan itu, sementara ia masih dalam ikatan perkawinan, -yang berarti ia berpoligami-, maka akad nikahnya dianggap batal. ${ }^{15}$ Dan pelaku poligami dikenai sanksi pidana. ${ }^{16}$

Di Mesir poligami dibolehkan, sama dengan di Indonesia. Yang berbeda adalah di Mesir lebih ketat, sebab -sebagaimana tersebut dalam UU 1977, UU No. 100/1985 bahwa seseorang yang akan menikah harus membuat surat pernyataan dalam surat lamarannya perihal status perkawinannya. Bila ia telah menikah, ia harus membubuhkan nama dan alamat isteri atau isteri-isterinya, sehingga pengadilan dapat memberi tahu perihal perkawinan suami mereka. Bila sang isteri mengetahui suaminya berpoligami, maka ia dapat mengajukan cerai ke pengadilan dengan alasan bahwa hal tersebut telah

\footnotetext{
${ }^{14}$ M. Quraish Shihab, "Era Baru, Fatwa Baru” Kata Pengantar dalam MB. Hooker, Islam Mazhab Indonesia Fatwa-Fatwa dan Perubahan Sosial (Jakarta: Teraju, 2002), h. 15.

${ }^{15}$ Khoiruddin Nasution, Status Wanita di Asia Tenggara: Studi terhadap Perundang-undangan Perkawinan Muslim Kontemporer di Indonesia dan Malaysia (Jakarta: INIS, 2002), h. 118.

${ }^{16}$ Tahir Mahmood, Family Law Reform in the Muslim World (New Delhi: The Indian Law Institute, 1979), h. 278.
} 
membawa kerugian ekonomi baginya. Hak pengajuan cerai isteri tersebut dibatasi selama satu tahun sejak ia mengetahui status perkawinan suaminya. Bila selama waktu satu tahun itu isteri tidak menggunakan haknya, maka hak tersebut dapat dicabut oleh pengadilan. Namun bila suaminya menikah lagi (berpoligami), maka hak itu diberikan kembali. Akan tetapi, bila isteri yang baru dinikahi tidak mengetahui status perkawinan suaminya, maka ia dapat mengajukan perceraian begitu ia mengetahuinya. ${ }^{17}$

Di Maroko dan Iran poligami juga dibolehkan. Hanya saja - kalau di Maroko sebagaimana dalam Undang-undang Status Pribadi 1958 -, isteri diberi hak untuk meminta suami agar ketika melangsungkan perkawinan membuat perjanjian bahwa jika ia ternyata nanti menikah lagi dengan wanita lain, maka perkawinannya yang pertama itu menjadi bubar dengan sendirinya. ${ }^{18}$ Sementara di Iran, seorang suami yang ingin menikah lagi, ia harus menyatakan secara tegas kepada isteri yang dinikahinya tentang status perkawinannya. Bila suami bohong, maka ia dikenai sanksi atas dasar tuntutan isteri. Demikian termaktub dalam UU 1931, pasal $6 .^{19}$ Di samping itu, sang suami harus mendapat izin terlebih dahulu dari pengadilan. Sebelum memberi izin, pengadilan harus meneliti lebih dahulu perihal kesanggupan yang bersangkutan (suami yang akan berpoligami) untuk menafkahi dan berlaku adi terhadap para isteri. Bila suami melanggar ketentuan ini, ia dikenai sanksi hukum. Demikian menurut Family Protection Law (FPL), 1967 pasal $14 .^{20}$

Namun di Tunisia, poligami dilarang dan pelakunya dikenai sanksi pidana berupa kurungan selama satu tahun dan denda sebesar 240.000 fank. Alasannya menurut al-

\footnotetext{
${ }^{17}$ Tahir Mahmood, Personal Law in Islamic Countries: History, Text The Muslim and Comparative Analysis, (New Delhi: Academy of Law and Religion, 1987), h. 39-40.

${ }^{18}$ M. Atho Mudzhar, Membaca Gelombang Ijtihad: Antara Tradisi dan Liberasi (Yogyakarta: Titian Ilahi Press, 1998), h. 184.

${ }^{19}$ Tahir Mahmood, Family, h. 155 dan 159.

${ }^{20}$ Tahir Mahmood, Family, h. 155-156, dan 162.
} 
Quran poligami itu harus didasari perlakuan adil dan al-Quran pula yang menyatakan bahwa kamu tidak akan mampu berlaku adil meskipun telah berupaya, apalagi adil dalam soal cinta. Itu berarti, bahwa poligami sebenarnya tidak dikehendaki oleh al-Quran. Terhadap riwayat yang menyebutkan bahwa ada hadis yang menyatakan bahwa keadilan itu tidak termasuk dalam soal cinta, Tunisia berpendapat bahwa hadis itu lemah dan tidak dapat dipegangi. ${ }^{21}$

\section{Karakteristik Pemikiran Hukum Islam}

Perbedaan peraturan perundang-undangan di negeri-negeri Islam di atas menunjukkan bahwa karakteristik pemikiran hukum Islam adalah pluralitas. Pluralitas opini hukum lebih kaya ditunjukkan oleh kitab-kitab fikih dan fatwa-fatwa ulama. Pluralitas opini hukum ini menggambarkan bahwa pemikiran hukum Islam tidak tunggal, melainkan beragam dan berbeda, yang secara teknis dinamakan ikhtilâf. Secara historis, perbedaan pendapat (ikhtilâf) bukan hal yang baru. Sejak zaman Nabi Saw. ikhtilâf sudah terjadi. Ketika Nabi saw. mengirim pasukan dalam perang Ahzab, beliau berpesan “Janganlah salah seorang kamu salat asar kecuali di Bani Quraizhah. Waktu asar tiba sementara sebagian mereka masih di tengah perjalanan. Berkata sebagian mereka: Jangan kita salat kecuali setelah sampai di bani Quraizhah. Sebagian lagi berpendapat: "Tidak, bukan itu yang dimaksud. Kita harus salat meskipun belum sampai di bani Quraizhah”. Kejadian ini kemudian diceritakan kepada Nabi Saw., dan Nabi pun tidak menyalahkan salah seorang dari mereka". ${ }^{22}$

\footnotetext{
${ }^{21}$ M. Atho Mudzhar, Membaca Gelombang Ijtihad, h. 183.
}

${ }^{22}$ Ibnu Hajar, Fath al-Bârî, Vol. VII, h. 313; Imam al-Bukhârî, Shahîh al-Bukhârî, Kitâb al-Maghâzî, Bâb Marji' al-Nabiyî Shallallâh 'alaih wa sallam min al-Ahzâb wa Makhrajihi ilâ Banî Quraizhah wa Muhâsharatihi iyyâhum, Hadis ke-3810. 
Pernyataan Nabi “Tidak seorang di antara kalian yang salat Ashar kecuali di Bani Quraizhah" dipahami sebagian sahabat secara tekstual. Karena itu, meskipun sudah tiba waktu ashar, mereka tidak melaksanakannya. Mereka melaksankannya setelah tiba di Bani Quraizhah. Dengan kata lain, yang menjadi ukuran pelaksanaan salat adalah tempat, yaitu di Bani Quraizhah. Karena itu, meskipun sudah tiba waktu salat, tetapi karena belum sampai di Bani Quraizhah, maka salat Ashar pun tidak dapat dilaksanakan. Jika dilaksanakan, jelas secara tekstual menyalahi perintah Nabi. Sebab, Nabi menegaskan untuk tidak salat Ashar kecuali di tempat Bani Quraizhah. Karena itu, akhirnya mereka mengakhirkan ashar hingga setelah Isya. Namun sebagian sahabat memahaminya secara substansial. Ukuran bagi mereka bukan tempat, melainkan waktu. Karena itu, Karena itu, mereka salat Ashar meskipun tidak di tempat Bani Quraizhah. Menurut mereka, secara substansial perintah Nabi di atas (agar tidak salat Ashar kecuali di Bani Quraizhah) mengandung arti “mempercepat perjalanan”, sehingga ketika tiba di Bani Quraizhah tepat waktu Ashar, atau maksimalnya sebelum Maghrib. Tetapi karena kenyataannya waktu Ashar telah tiba, sementara belum sampai di tempat yang dituju, Bani Quraizhah, maka shalat Ashar pun harus dilakukan di perjalanan.

Contoh ikhtilâf sahabat di atas, menunjukkan bahwa secara prinsipil nash-nash hukum memang menyediakan ruang gerak dan framework bagi kemungkinan-bahkan keniscayaan- adanya perbedaan sudut pandang dan metodologis. Justru karena sifat-sifat inilah hukum Islam dapat terus hidup dan dinamis di tengah-tengah beragam tuntutan zaman sekalipun, tegas Yûsuf al-Qardhâwî. ${ }^{23}$ Dalam konteks ini, dapat dipahami

${ }^{23}$ Yûsuf al-Qardhâwî, 'Awamil al-Si'ah wa al-Murûnah fî al-Syarî'ah al-Islâmiyah, (Kairo: t. p., 1985), h. 47-63. 
pernyataan al-Qâsim, cucu Abû Bakar, "Allah menyukai kita dengan ikhtilâf yang dilakukan oleh sahabat Rasulullah dalam perbuatan mereka. Seseorang bebas memilih salah satu dari perbuatan mereka." ${ }^{24}$ Khalifah 'Umar ibn 'Abdul Azîz juga berkata, "Saya tidak suka bahwa sahabat Rasulullah Saw. harus tidak berbeda pendapat, sebab apabila hanya ada satu pendapat, masyarakat akan terjebak dalam kesempitan". ${ }^{25}$ Ini berarti, demikian ahli hukum Imam al-Syâthibî berkomentar, para sahabat telah membuka pintu ijtihad dan membolehkan perbedaan pendapat didalamnya. Jika hal itu tidak dilakukan, para mujtahidin akan mengalami kesulitan, karena bidang ijtihad dan bidang-bidang pemikiran lainya seringkali tidak ditemukan titik temunya. ${ }^{26}$

Keniscayaan perbedaan pendapat hukum ini kemudian melahirkan berbagai mazhab hukum, terutama sekitar abad II hingga menjelang abad III H yang dikenal dalam sejarah hukum Islam dikenal sebagai era keemasan fikih. ${ }^{27}$ Menurut Thaha Jâbir Fayadh al-'Ulwânî menyebut tidak kurang dari 13 aliran yang muncul pada era ini. Ketiga belas aliran ini berafiliasi dengan Ahlussunnah. ${ }^{28}$ Dari tiga belas mazhab yang muncul saat itu hanya empat mazhab yang masuk "nominasi" untuk memperoleh legitimasi dari generasi

\footnotetext{
${ }^{24}$ Ibnu Abdil Barr, Jami’ Bayan al- 'Ilm wa Fadhlih, Vol. III, h. 80.

${ }^{25}$ Imâm al-Syâthibî, al- 'I'tishâm, Vol. III, h. 11.

${ }^{26}$ al-Syâthibî, al- 'I’tishâm, Vol. III, h. 11.

${ }^{27}$ Khudhari Beik menyebutnya fase fikih menjadi ilmu yang mandiri;Khudhari Beik, Târikh al-
} Tasyrî' al-Islâmî (Surabaya: Muhammad Nabhan, t. th.), h. 4-5. Hasbi al-Shiddiqi menamainya sebagai fase kesempurnaan. T. M. Hasbi al-Shiddiqi, Pokok-Pokok Pegangan Imam-Imam Madzhab dalam Membina Hukum Islam (Jakarta: Bulan Bintang, 1973), h. 31-32.

${ }^{28}$ Ketiga belas aliran itu adalah Abû Sa'id al-Hasan ibn Yasar al-Bashrî (w. 110 H); Abû Hanîfah alNu'mân ibn Tsâbit ibn Zuthi (w. 150 H); Al-Auza'î Abû 'Amar 'Abdurrahmân ibn 'Amr ibn Muhammad (w. 157 H); Sufyân ibn Sa'îd ibn Masrûq al-Tsaurî (w. 160 H); Al-Laits ibn Sa'd (w. 175 H); Mâlik ibn Anas al-Bahî (w. 179); Sufyân ibn 'Uyainah (w. 198 H); Muhammad ibn Idrîs al-Syâfi' î (w. 204 H); Ahmad ibn Muhammad ibn Hanbal (w. 241 H); Dâwud ibn 'Ali al-Ashbahânî al-Baghdâdî (w. 270); Ishâq ibn Rahawaih (w. 238 H); dan Abû Tsaur Ibrâhîm ibn Khâlid al-Kalabî (w. 240 H).Thâha Jâbir Fayadh al'Ulwânî, Adâb al-Ikhtilâf (Washington: The International Institute of Islamic Though, 1987), h. 87-88. Lihat pula Mun'im A. Sirry, Sejarah Fiqih Islam, Sebuah Pengantar (Surabaya: Risalah Gusti, 1996), h. 79-80; dan Jaih Mubarak, Sejarah dan Perkembangan Hukum Islam (Bandung: Rosda Karya, 2000), h. 70-71 dan 132. 
berikutnya. ${ }^{29}$ Keempat mazhab yang (kemudian dikenal dengan madzâhib al-arba'ah: Hanafî, Mâlikî, Syâfi'î dan Hanbalî) berhasil bertahan setelah melalui pertarungan sengit dan seleksi alam yang ketat, memperoleh legitimasi dari generasi berikutnya sebagai mazhab resmi. Menurut Qâdhî 'Iyâdh dalam karyanya al-Madârik, sebagaimana dikutip al-Hajwî, menyatakan bahwa proses seleksi sejarah (dari tiga belas menjadi empat mazhab) itu berlangsung hingga abad ke-6 H. Imam al-Suyûthî menganalisa proses itu berlangsung selama 500 tahun sejak munculnya mazhab-mazhab tersebut. ${ }^{30}$

Yang menarik untuk dipertanyakan adalah mengapa hanya empat mazhab yang bertahan, sedangkan lainnya lenyap? Satu diantara faktornya adalah karena adanya dukungan penguasa. Mazhab Hanafî berkembang ketika Abû Yûsuf, murid Abû Hanifah diangkat menjadi Qâdhi al-Qudhât (Hakim Agung) pada masa pemerintahan tiga khalifah Abbasiyah: al-Mahdî, al-Hâdî dan Harun al-Rasyîd. Mazhab Malikî lestari karena dukungan al-Manshûr Khilafah Timur dan Yahyâ ibn Yahyâ ketika diangkat menjadi qâdhi oleh penguasa Andalusia. Mazhab Syâfi'î membesar di Mesir setelah Shalâhuddîn al-Ayubî merebut negeri itu. Dan mazhab Hanbalî menjadi kuat setelah Mutawakkil diangkat menjadi khalifah Abbasiyah. ${ }^{31}$ Tegasnya sebuah aliran dapat berkembang subur karena adanya dukungan politik kekuasaan. Tetapi terlepas adanya faktor politik, yang jelas lenyapnya mazhab-mazhab itu memberi suatu pemahaman yang amat penting: bahwa undang-undang, hukum dan berbagai pemikiran secara umum bukan sesuatu yang abadi (eternal), melainkan merupakan refleksi kehidupan sosial, yang berarti pula bahwa

\footnotetext{
${ }^{29}$ Mun'im A. Sirry, Sejarah Fiqih Islam, Sebuah Pengantar, h. 79.

${ }^{30}$ Farouq Abu Ziad, Hukum Islam: Antara Tradisionalis dan Modernis, terj. Husein Muhammad, (Jakarta: P3M, 1986), h. 1-2.

${ }^{31}$ Jaih Mubarak, Sejarah dan Perkembangan Hukum Islam (Bandung: Rosda Karya, 2000), h. 132133.
} 
seseorang harus berlepas diri dari penghambaan (ibadah) kepada selain Allah, menghadapkan hati sepenuhnya hanya untuk beribadah kepada Allah. ${ }^{32}$

Ia akan terus tumbuh dan berubah sejalan dengan perubahan masyarakat dan zamannya. Namun pada kenyataannya terlalu banyak orang-orang yang menyianyiakan waktu, dengan hidup santai dibuai oleh mimpi-mimpi, lamunan-lamunan yang tidak pernah dapat menyelesaikan masalah. ${ }^{33}$ Dalam Undang-undang dan peraturan-peraturan memiliki kondisi khusus untuk menerima perubahan dan pembaharuan seiring dengan perubahan kondisi masyarakat. ${ }^{34}$

Dengan demikian, perkembangan pemikiran hukum Islam tidak dapat dilepaskan dari unsur politik dan perubahan masyarakat. Dengan ungkapan lain, selain pluralitas, karakteristik pemikiran hukum Islam adalah politis dan dinamis. Beberapa produk hukum Islam di Indonesia, tidak akan lahir kalau tanpa ada dukungan politik kekuasaan. Hukum Islam yang lahir oleh dukungan kekuasaan, belakangan disebut mazhab negara. Adapun pemikiran hukum Islam yang bersifat dinamis karena adanya tuntutan dinamika perkembangan dan perubahan masyarakat. Belakangan produk-produk hukum Islam dinamis tersebut masuk dalam wilayah fikih kontemporer. Hal lain juga disampaikan Syekh Yusuf selalu meninggalkan jejak keislaman dengan merubah masyarakat jahiliyah menjadi masyarakat yang Islami dan berperadaban. ${ }^{35}$

\footnotetext{
${ }^{32}$ Sainuddin, I. H., S, Arsyam, M., \& Alwi, A. M. S. (2020, August 19). Pemahaman Makna Tauhid dan Dua Kalimat Syahadat. https://doi.org/10.31219/osf.io/g84vu

${ }^{33}$ Arsyam, M., \& Alwi, A. M. (2020). MANAJEMEN HIDUP DALAM PERSPEKTIF ALQUR'AN.

${ }^{34}$ Muhammad ibn Hasan al-Hajwî, Al-Fikr al-Samî (Madinah: Maktabah al-'Ilmiyah, 1977), h. 67.

${ }^{35}$ Sainuddin, I. H., Arsyam, M., Wekke, I. S., Rajjako, A., \& Raya, H. M. I. C. G. Syekh Yusuf AlMakassari; Pengembangan Masyarakat Islam.
} 


\section{Corak Pemikiran Hukum Islam}

Pemikiran hukum Islam ada yang bercorak literalistik-tekstualistik. Disebut literalistik karena penyimpulan opini hukum yang dideduksi dari al-Quran dan hadis didekati secara literalistik. Apa yang dinyatakan oleh teks, itulah yang diperpegangi. Karena itu, ciri menonjol pemikiran Hukum Islam literal adalah menangkap pesan ayat berdasarkan bunyi tekstualnya. Dalam sejarah pemikiran hukum Islam, Ibnu Hazm dipandang sebagai tokoh literalis. Ia dikenal pelanjut dan pengawal mazhab Zhâhirî. Mazhab Zhâhirî adalah mazhab yang memahami al-Quran dan hadis secara tekstualistik. Karena itu, tidak sedikit pendapatnya yang berseberangan dengan pendapat Imam Mazhab. Dalam Q.S. al-Mâidah/5 ayat 3 disebutkan bahwa mengkonsumsi daging babi adalah haram. ${ }^{36}$ Dalam pemahaman Ibnu Hazm, penyebutan daging babi (lahrm alkhinzîr) dalam ayat tersebut bersifat takhshîsh (spesifikasi). Itu berarti, hanya dagingnya yang diharamkan. Adapun selainnya, seperti tulang atau sumsumnya adalah dibolehkan.

Dalam Q.S. al-Baqarah/2 ayat 184 disebutkan bahwa orang sakit dan dalam perjalanan dibolehkan untuk tidak puasa, tetapi harus menggantinya di hari lain. ${ }^{37}$ Karena itu, jika orang sakit tersebut berpuasa, maka puasanya tidak sah. ${ }^{38}$ Ibnu $\underline{\text { Hazm memahami }}$ sakit dalam pengertian sakit apa saja. Karena itu, menurutnya orang yang sakit mata boleh untuk tidak puasa.

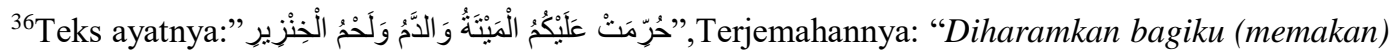
bangkai, darah dan daging babi".

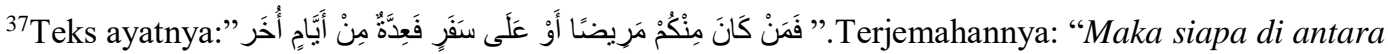
kalian dalam keadaan sakit atau sedang dalam perjalanan, maka (boleh tidak puasa), tetapi menggantinya di hari lain".

${ }^{38}$ Muhammad Ibrâhim Jannatî, Durûs fî al-Fiqh al-Muqâran, Jil. II, terj. Ibnu Alwi Bafaqih, et. al., Fiqh Perbandingan Lima Mazhab (Jakarta: Cahaya, 2007), h. 34.
} 
Selain sakit, bepergian (al-safar) menjadi alasan untuk tidak wajib berpuasa. Safar artinya perjalanan. Sebutan perjalanan menunjukkan bahwa orang yang melakukan safar meninggalkan rumah; menempuh -jarak- perjalanan; dan perjalanan itu membutuhkan

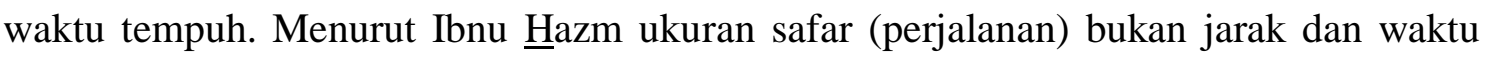
tempuh, melainkan perjalanan itu sendiri yang ditandai dengan keluar dan meninggalkan tempat tinggal. Itu berarti, dalam pandangan Ibnu Hazm setiap bepergian ke luar rumah

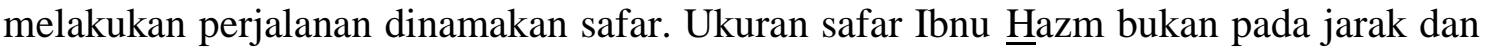
waktu tempuh perjalanan, tetapi meninggalkan rumah pergi melakukan perjalanan. Dengan kata lain, anda meninggalkan rumah menuju suatu tempat, maka anda sudah termasuk ke dalam pengertian safar menurut Ibnu Hazm; meskipun perjalanan yang anda tempuh itu di bawah $84 \mathrm{~km}$ dan atau waktu tempuhnya kurang dari sehari semalam. Dan karena itu, anda boleh tidak puasa. Bila anda puasa, dengan alasan anda mampu, maka dalam perspektif tekstualistik Ibnu Hazm, puasa anda tidak sah. Ini berbeda dengan pandangan mayoritas, yang menyatakan puasa sah yang dilakukan orang sakit dan orang dalam perjalanan.

Dalam buku Tafsir Hukum: Tema-Tema Kontroversial Sofyan A.P. Kau menyebut sejumlah pendapat yang bercorak tekstualistik. Diantaranya pendapat yang menegaskan kepemimpinan laki-laki atas kaum perempuan, sebab kepemimpinan wilayah publik kaum laki-laki. Sementara hak dan wilayah perempuan adalah dunia domestik. Karenanya, perempuan haram menjadi pemimpin, karena kepemimpinan adalah hak kaum laki-laki. Demikian kesimpulan secara literalistik atas pembacaan Q.S. al-Nisâ'/4 ayat 43. Selain literal, ada juga pemikiran hukum Islam yang bercorak kontekstual. Yaitu pemahaman yang mengaitkan dengan latar belakang sosial ayat itu 
turun (sabab al-nuzûll). Menurut pemahaman kontekstual, ayat 43 surat al-Nisâ' di atas berdasarkan sabab al-nuzûl, ayat tersebut turun berkenaan dengan kasus rumah tangga, atau lebih spesifik berkaitan dengan kasus ranjang. Bahwa seorang sahabat menampar isterinya karena menolak hubungan badan. Ketika sang isteri melapor kepada Nabi Saw. atas tamparan suaminya, dan saat mana Nabi Saw. memperkenankan hukuman balas, tiba-tiba ayat ini turun. Tegasnya, secara kontekstual ayat tersebut terlalu jauh ditarik ke wilayah publik, karena kasusnya lebih bersifat individual dan domestik. ${ }^{39}$

Ada juga pemikiran hukum Islam yang bercorak liberal. Yaitu pemikiran hukum Islam yang melampaui pemikiran ulama hukum klasik. Bahkan berseberangan dengan pendapat mayoritas ulama. Seperti kebolehan perempuan menjadi imam salat. Jika mayoritas ulama berpendapat bahwa perempuan tidak boleh menjadi imam salat atas kaum laki-laki, maka pemikiran hukum Islam liberal membolehkannya. Kebolehan ini didasarkan kepada hadis yang terdapat Musnad Ahmad Ibn $\underline{H} a n b a l$ dan Sunan Abî Dâwûd disebutkan:

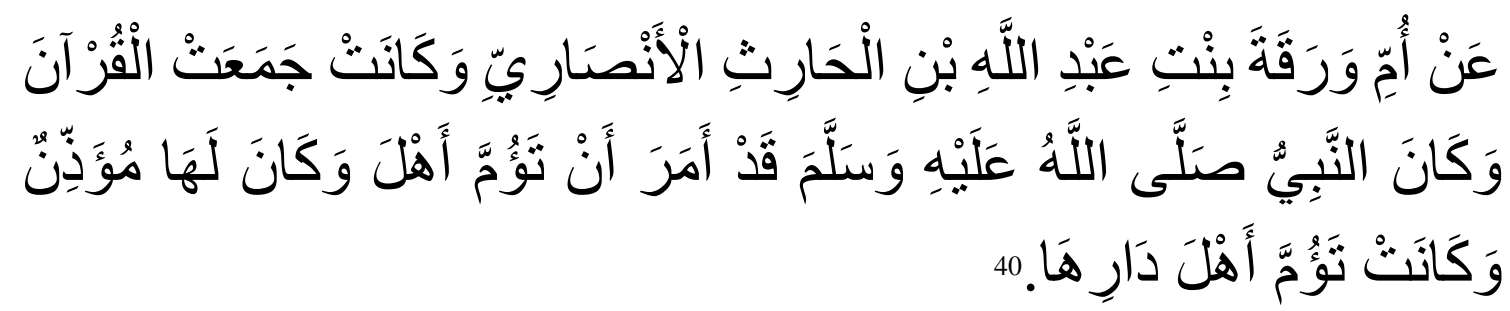

Artinya:

"Dari Ummu Waraqah binti 'Abdullâh ibn al-Hârits al-Anshârî, ia adalah seorang yang pernah mengumpulkan al-Quran. Adalah Nabi Saw. pernah menyuruhnya menjadi imam bagi penghuni rumahnya. Ia juga memiliki seorang muazin. Lalu ia pun mengimami keluarganya".

\footnotetext{
${ }^{39}$ Sofyan A. P. Kau, Tafsir Hukum: Tema-Tema Kontroversial, dari Pendekatan Tradisional hingga Liberal, (Gorontalo: Sultan Amai Press, 2006), h. 92-123.

${ }^{40}$ Imâm Aḥmad Ibn Hanbal, Musnad A $\underline{h} m a d$ Ibn Hanbal, Juz IV (Beirut: al-Maktab al-Islâmî, 1398 H/1979 M), h. 405.
} 


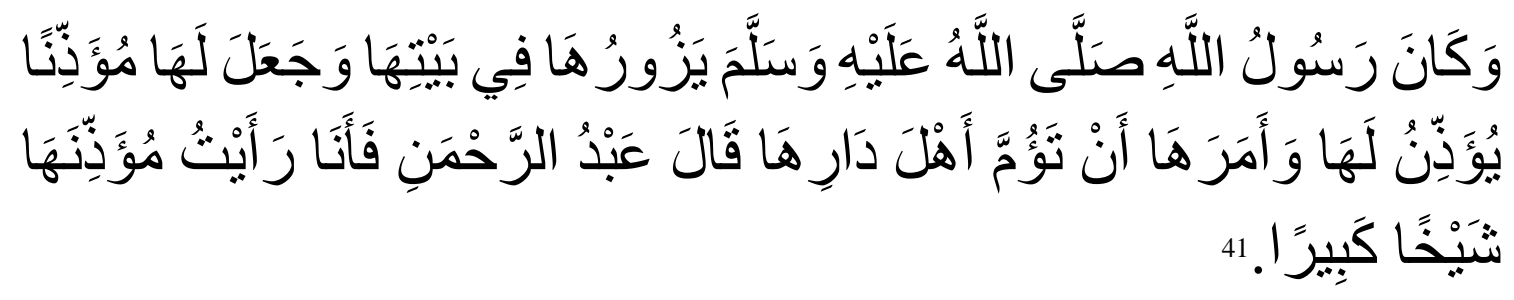

Artinya:

"Nabi saw. pernah mendatangi rumahnya (Ummu Waraqah binti 'Abdullâh ibn alHârits al-Anshârî). Beliau memberinya seorang muazin dan menyuruhnya menjadi imam bagi penghuni rumahnya. 'Abdurrahmân berkata: Sungguh, aku benar-benar melihat muazinnya adalah seorang laki-laki tua."

Kedua hadis di atas menegaskan dua hal: Pertama, bahwa Ummu Waraqah menjadi imam salat bagi keluarganya dalam salat fardhu. Selain makmum perempuan, ada juga makmum laki-laki. Sayyid Sâbiq menyebut, seorang laki-laki. ${ }^{42}$ Agaknya yang dimaksud dengan seorang laki-laki yang menjadi makmum itu adalah syaikhan kabîran, laki-laki tua yang dilihat oleh 'Abdurrahmân sebagai muazin. Kedua,kedua hadis di atas bersumber dari Ummu Waraqah. Agaknya hadis yang berkenaan dengan kebolehan wanita menjadi imam salat, umumnya bersumber dari Ummu Waraqah. Meskipun satu sumber, namun terdapat sejumlah perbedaan. Tidak hanya perbedaan redaksional sebagaimana terlihat dalam kedua hadis di atas, namun pada periwayat dan mukharrijnya juga berbeda. Misalnya hadis yang dikeluarkan oleh (mukharrij) al-Daruqthunî, sebagaimana dikutip Wahbah al-Zuhaylî dalam Al-Fiqh al-Islâmî wa Adillatuhu- yang berbunyi:

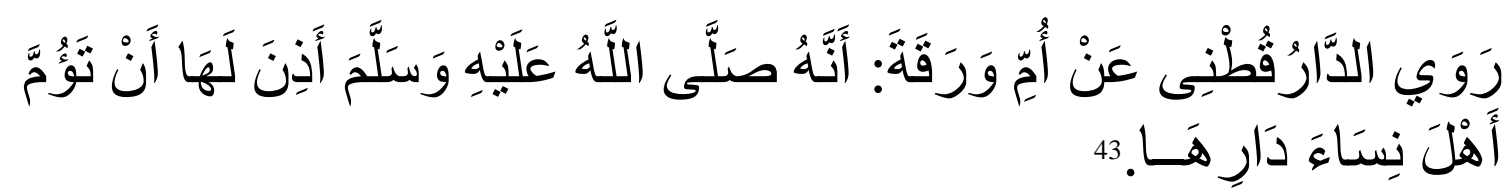

Artinya:

"Al-Dâruqthnî meriwayatkan dari Ummu Waraqah bahwa Nabi Saw. mengizinkannya menjadi imam salat bagi kaum perempuan penghuni rumahnya".

${ }^{41}$ Al-Imâm al-Hâfizh Sulaimân al-Asy’ats al-Sajastânî Abû Dâwud, Sunan Abî Dâwud, Juz II, ditahqiq dan dita'liq oleh Muhammad 'Abdul 'Azîz al-Khâlidî, (Beirût: Dâr al-Kutub al-'Ilmiyyah, 1996 M/1416 H), Kitâb al-Shalâh Bâb Imâmah al-Nisâ', Hadis ke-500.

${ }^{42}$ Sayyid Sâbiq, Fiqh al-Sunnah, Jil. I (Beirut: Dâr al-Fikr, t. th.), h. 200.

${ }^{43}$ Wahbah al-Zuhaylî, Al-Fiqh al-Islâmî wa Adillatuhu, Jil. II (Damaskus: Dâr al-Fikr, 1997), h. 175. 
Apa implikasi hukumnya atas perbedaan ketiga hadis di atas? Dua hadis yang disebut pertama, secara redaksional memang berbeda. Namun keduanya secara substansial adalah sama. Keduanya menggambarkan bahwa Ummu Waraqah mengimami salat jamaah keluarganya. Yang ia imami selain makmum perempuan, juga ada laki-laki; yaitu seorang laki-laki tua yang menjadi muazin di rumahnya. Namun pada hadis yang ketiga yang diriwayatkan oleh Imam al-Daruqthunî, terlihat Ummu Waraqah hanya diizinkan oleh Nabi saw. untuk mengimami keluarga yang perempuan. Karena itu, berdasarkan hadis ini, Wahbah al-Zuhaylî, seorang pakar hukum Islam kontemporer asal Syiria ini berkesimpulan bahwa wanita hanya sah menjadi imam salat bagi jamaah wanita. Adapun untuk jamaah bagi laki-laki adalah tidak boleh. ${ }^{44}$

Benar bahwa hadis yang dikutip Wahbah al-Zuhaylî menegaskan bahwa Ummu Waraqah hanya mengimami kaum wanita atas perkenan Nabi. Tetapi hadis riwayat alDaruqthunî, memperoleh penjelasan lebih lanjut dalam hadis lainnya, seperti yang diriwayatkan oleh Imam Ahmad ibn Hanbal dan Abû Dâwud. Bahwa yang ikut berjamaah, selain perempuan juga seorang laki-laki. Bahkan menurut al-Shana'ânî alKahlânî dalam karya komentarnya atas Bulûgh al-Marâm susunan Ibnu Hajar al'Asqalânî,Subul al-Salâm, menegaskan bahwa yang menjadi makmum dalam salat yang diimami Ummu Waraqah adalah selain seorang laki-laki tua, juga seorang laki-laki hamba sahaya dan perempuan hamba sahaya. ${ }^{45}$

Terlepas berapa jumlah laki-laki yang menjadi makmum Ummu Waraqah, tetapi yang pasti Ummu Waraqah menjadi imam salat bagi laki-laki dan wanita.

\footnotetext{
${ }^{44}$ Wahbah al-Zuhaylî, Al-Fiqh, h. 175.

${ }^{45}$ Al-Sayyid al-Imâm Muhammad ibn Ismâ'̂̂l al-Kahlânî al-Shana’ânî Subul al-Salâm, Juz I, (Bandung: Dahlan, t. th.), h. 35.
} 
Lalu apakah dengan berdasarkan konteks dan makna literal hadis di atas boleh menjadi imam salat laki-laki dan wanita? Boleh! Berdasarkan konteks hadis tersebut, kebolehan itu hanya berlaku dalam lingkungan keluarga sendiri; dan tidak berlaku umum.

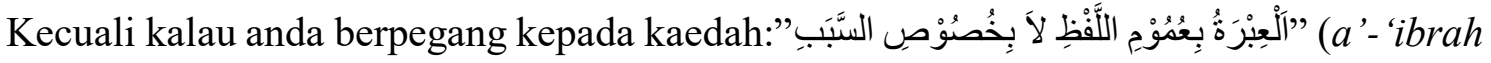
bi 'umûm al-lafzh lâ bi khushûsh al-sabab), yaitu: bahwa yang menjadi ukuran adalah bukan peristiwa yang melatarbelakanginya, sebab hal itu bersifat kasuistik. Akan tetapi yang menjadi pegangan adalah pesan global dari peristiwa itu. 


\section{E. Kesimpulan}

Uraian di atas menunjukkan bahwa hukum Islam bukan produk pemikiran yang statis melainkan dinamis. Dinamika pemikiran hukum Islam tersebut dibentuk oleh ijtihad. Karena itu Ijtihad memegang peranan penting dalam menggali dan mengembangkan hukum Islam dan ilmu-ilmu keislaman lainnya. Demikian penting peranannya sehingga Ali Hasaballah dan Harun Nasution menjadikan ijtihad sebagai sumber ketiga dari hukum Islam setelah al-Quran dan hadis. Bahkan Harun, tokoh utama teologi rasional, menyatakan bahwa "pada hakekatnya ijtihadlah yang menjadi kunci dinamika Islam.”

Makalah ini mendeksripsikan tentang hukum Islam yang dinamis. Dinamika hukum Islam lahir melalui proses ijtihad progresif. Ijtihad progresif melahirkan empat produk hukum Islam, yaitu fikih, fatwa, perundang-undangan di negeri Muslim (qanun) dan putusan pengadilan (qadha). Keempat produk pemikiran hukum Islam tersebut kaya dengan keragamana pendapat (ikhtilaf). Dalam fikih Sunni lahir lima mazhab fikih popular (Hanafi, Maliki, Syafi'i, Hanbali dan Zhahiri) dengan corak pemikiran yang berbeda. Hanafi rasional, Maliki cenderung kepada pendapat ahlul Madinah, Syafi'i moderat, Hanbali mengedepankan makna lahir hadis dan Zhahiri tekstual. 


\section{F. DAFTAR PUSTAKA}

A. P. Kau, Sofyan. Fikih Alternatif. Gorontalo: Sultan Amai Press, 2010.

A. P. Kau, Sofyan. Metode Penelitian Hukum Islam. Gorontalo: Sultan Amai Press, 2009.

A. P. Kau, Sofyan. Tafsir Hukum: Tema-Tema Kontroversial, dari Pendekatan Tradisional hingga Liberal. Gorontalo: Sultan Amai Press, 2010.

Abû Dâwud, Al-Imâm al-Hâfizh Sulaimân al-Asy’ats al-Sajastânî. Sunan Abî Dâwud, Juz II, ditahqiq dan dita'liq oleh Muhammad 'Abdul 'Azîz al-Khâlidî. Beirût: Dâr alKutub al-'Ilmiyyah, 1996 M/1416 H.

Abû Zahrah, Muhammad. Ushûl al-Fiqh. Mesir: Dâr al-Fikr al-'Arabî, t. th.

Al-'Âmidî, Saifuddîn. Al-I $\underline{h k a ̂ m}$ fì Ushûl al-A $\underline{h} k \hat{a} m$. Jil. I. Kairo: Muassasah al-Halabî, 1967.

Arsyam, M., \& Alwi, A. M. (2020). MANAJEMEN HIDUP DALAM PERSPEKTIF ALQUR'AN.

Assyaukanie, Luthfi. Islam Benar Versus Islam Salah. Jakarta: Kata Kita, 2007.

Barr, Ibnu Abdil. Jami’ Bayan al- 'Ilm wa Fadhlih, Vol. III.

Beik, Khudhari. Târikh al-Tasyrî’ al-Islâmî. Surabaya: Muhammad Nabhan, t. th.

Dahlan, Abdul Aziz, et al. Ensiklopedi Hukum Islam. Vol. 2. Jakarta: Ichtiar Baru Van Hoeve, 1996.

El Fadl, Khaled M. Abou. Speaking in God's Name: Islamic Law, Authority, and Women. Terj. R. Cecep Lukman Yasin, Atas Nama Tuhan Dari Fikih Otoriter ke Fikih Otoritatif. Jakarta: Serambi Ilmu Semesta, 2004.

Hajwî, Muhammad ibn Hasan. Al-Fikr al-Samî. Madinah: Maktabah al-'Ilmiyah, 1977.

Hasaballah, Ali. Ushul al-Tasyri' al-Islami. Kairo: Dar al-Ma'arif, 1964.

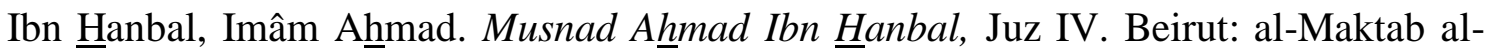
Islâmî, 1398 H/1979 M.

Jannatî, Muhammad Ibrâhim. Durûs fî al-Fiqh al-Muqâran. Jil. II. Terj. Ibnu Alwi Bafaqih, et. al., Fiqh Perbandingan Lima Mazhab. Jakarta: Cahaya, 2007.

Mahmood, Tahir. Family Law Reform in The Muslim World. New Delhi: The Indian Law Institute, 1979.

Mahmood, Tahir. Personal Law in Islamic Countries: History, Text The Muslim and Comparative Analysis. New Delhi: Academy of Law and Religion, 1987.

Mubarak, Jaih. Sejarah dan Perkembangan Hukum Islam. Bandung: Rosda Karya, 2000.

Mudzhar, M. Atho. Membaca Gelombang Ijtihad: Antara Tradisi dan Liberasi. Yogyakarta: Titian Ilahi Press, 1998. 
Muslihuddin, Muhammad. Philosofhy of Islamic Law and Orientalist: A Comparative Study of Islamic Legal System. Lahore, Pakistan: Islamic Publication, t.th.

Nabhân, Fârûq. Al-Madkhal li al-Tasyrî‘ al-Islâmî. Beirût: Dâr al-Shadr, t.th.

Nasution, Harun. "Ijtihad Sumber Ketiga Ajaran Islam," dalam Haidar Baqir dan Syafiq Basri (ed.), Ijtihad Dalam Sorotan. Bandung: Mizan, 1988.

Nasution, Khoiruddin. Status Wanita di Asia Tenggara: Studi terhadap Perundangundangan Perkawinan Muslim Kontemporer di Indonesia dan Malaysia. Jakarta: INIS, 2002.

Praja, Juhaya S. "Dinamika Hukum Islam", dalam Jaih Mubarak, Sejarah dan Perkembangan Hukum Islam. Bandung: Rosda Karya, 2000.

Al-Qardhâwî, Yûsuf. 'Awamil al-Si'ah wa al-Murûnah fî al-Syarî'ah al-Islâmiyah. Kairo: t.p., 1985.

Al-Qaththân, Mannâ‘. Al-Tasyrî‘ wa al-Fiqh fî al-Islâmî. Riyâdh: Muassasah al-Risâlah, t.th.

Al-Qaththân, Mannâ'. Târikh al-Tasyrî‘ al-Islâmî: Al-Tasyri ‘ wa al-Fiqh. Riyâdh: Maktabah al-Ma'ârif, 1422 H.

Sâbiq, Sayyid. Fiqh al-Sunnah. Jil. I. Beirut: Dâr al-Fikr, t. th.

Sainuddin, I. H., S, Arsyam, M., \& Alwi, A. M. S. (2020, August 19). Pemahaman Makna Tauhid dan Dua Kalimat Syahadat. https://doi.org/10.31219/osf.io/g84vu

Sainuddin, I. H., Arsyam, M., Wekke, I. S., Rajjako, A., \& Raya, H. M. I. C. G. Syekh Yusuf Al-Makassari; Pengembangan Masyarakat Islam.

Schacht, Joseph. An Intoduction to Islamic Law. Oxford: Clarendon Press, 1993.

Al-Shana'ânî. Al-Sayyid al-Imâm Muhammad ibn Ismâ'îl al-Kahlânî. Subul al-Salâm, Juz I. Bandung: Dahlan, t.th.

Ash-Shiddieqy, Hasbi. Filsafat Hukum Islam. Semarang: Pustaka Rizki Putra, 2001.

Ash-Shiddieqy, T. M. Hasbi. Pokok-Pokok Pegangan Imam-Imam Madzhab dalam Membina Hukum Islam. Jakarta: Bulan Bintang, 1973.

Shihab, M. Quraish. "Era Baru, Fatwa Baru” Kata Pengantar dalam MB. Hooker, Islam Mazhab Indonesia Fatwa-Fatwa dan Perubahan Sosial. Jakarta: Teraju, 2002.

Sirry.Mun'im. Sejarah Fiqih Islam, Sebuah Pengantar. Surabaya: Risalah Gusti, 1996.

Al-Syâthibî, Imâm. Al- 'I'tishâm, Vol. III.

Ziad, Farouq Abu. Hukum Islam: Antara Tradisionalis dan Modernis. Terj. Husein Muhammad. Jakarta: P3M, 1986.

Al-Zuhaylî, Wahbah. Al-Fiqh al-Islâmî wa Adillatuhu. Jil. II. Damaskus: Dâr al-Fikr, 1997. 